\title{
Site Monitoring and Numerical Modelling of a Trial Embankment's Behaviour on Venice Lagoon Soils
}

\author{
Valentina Berengo, ${ }^{1}$ Thomas Benz, ${ }^{2}$ Paolo Simonini, ${ }^{3}$ and Martino Leoni ${ }^{4}$ \\ ${ }^{1}$ Geotechnics and Structure Department, NET Engineering S.p.A., 35043 Monselice, Italy \\ ${ }^{2}$ Norwegian University of Science and Technology (NTNU), 7491 Trondheim, Norway \\ ${ }^{3}$ IMAGE Department, University of Padova, 35129 Padova, Italy \\ ${ }^{4}$ Wesi Geotecnica Srl, 54100 Massa, Italy \\ Correspondence should be addressed to Martino Leoni, martino.leoni@wechselwirkung.eu
}

Received 24 May 2011; Accepted 21 June 2011

Academic Editors: Y. Lai and M. T. Tumay

Copyright $\odot 2011$ Valentina Berengo et al. This is an open access article distributed under the Creative Commons Attribution License, which permits unrestricted use, distribution, and reproduction in any medium, provided the original work is properly cited.

\begin{abstract}
Mineralogical and mechanical characterization of Venice lagoon soils is required for design and construction of movable floodgates that aim to safeguard the city of Venice against recurrent floods. An instrumented circular test embankment was constructed in the lagoon area, enabling accurate measurement of relevant ground displacements. In situ stress-strain-time measurements were carried out in order to investigate the viscous behaviour of Venice lagoon soils during and after embankment loading. Site monitoring was kept up also during embankment removal so that information on soil behaviour in unloading is available, too. This paper illustrates key results from embankment monitoring and also focuses on modelling of creep behaviour. A recently developed anisotropic constitutive model was calibrated for Venice lagoon soils and is used in back analysis of the embankment construction and removal process. The constitutive parameters of the model were calibrated from in situ and laboratory tests.
\end{abstract}

\section{Introduction}

The worldwide-known historic city of Venice and the surrounding lagoon is suffering overall rapid deterioration, caused mainly by an increasing flood frequency due to the eustatic sea level rise, coupled with a natural and man-induced subsidence, the latter particularly significant between 1946 and 1970.

The importance of preserving the historic city has, therefore, stimulated the proposal of numerous technical solutions, including movable gates located at the three lagoon inlets (i.e., Malamocco, Chioggia, and Lido) to control water levels within the lagoon. These gates temporarily separate the lagoon from the sea at the occurrence of particularly high tides, which have increased notably and in frequency.

Standard geotechnical investigations were, therefore, performed at the inlets, and recently, two test sites were selected, where investigations on the main properties of the Venetian soils have been concentrated.
The main characteristic of the lagoon soils is the presence of a predominant silty fraction, combined with clay and/or sand [1]. These form a chaotic interbedding of different sediments, whose basic mineralogical characteristics vary narrowly, as a result of unique geological origins and a common depositional environment. This latter feature, together with the relevant heterogeneity of soil layering, seemed to suggest concentrating the main research efforts on selected test sites, considered as representative of typical soil profiles, where relevant in situ and laboratory investigations could be carried out in the careful characterization of the Venetian lagoon soils.

At the first test site, located at the Malamocco inlet, a series of investigations including boreholes, piezocone, dilatometer, pressuremeter, and cross-hole tests were performed on contiguous verticals. In addition, a comprehensive laboratory characterization was carried out [1].

A second test site, namely, the Treporti test site, was then selected to measure the site stress-strain-time behaviour of Venice lagoon soils. A vertically walled circular embankment, 


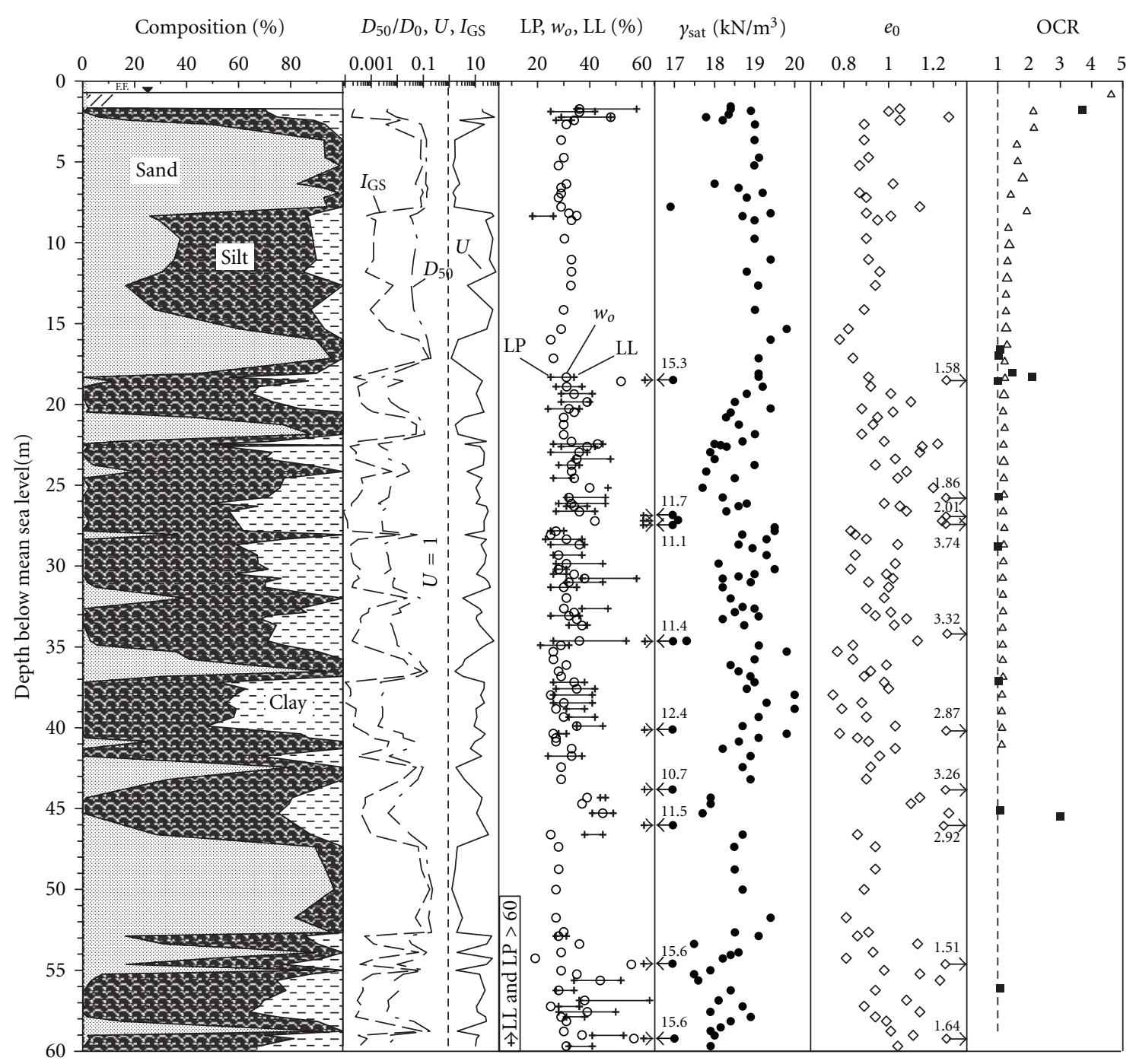

$\triangle$ Embankment monitoring
- Oedometer test

FIgURE 1: Soil profile, basic properties, and stress history at the Treporti test site.

loading up the ground to slightly above $100 \mathrm{kPa}$, was constructed, measuring, during and after the construction, the relevant ground displacements together with the pore pressure evolution. To this end, the ground beneath the embankment was heavily instrumented using plate extensometer, differential micrometers, GPS, inclinometers, piezometers, and load cells. Seismic piezocone and laboratory tests on soil samples taken with the Osterberg sampler were used to characterize soil profile and estimate the soil properties for comparison with those directly measured in situ. Horizontal and vertical ground displacements, together with pore pressure evolution, were measured during construction and for four years thereafter [2]. The embankment was then removed in three stages, after each of them the embankment level was kept constant for three months, in order to capture the possible creep behaviour after a swelling phase [3].
A numerical analysis was then carried out in order to model the mechanical behaviour of the subsoil. To this end, the finite element code PLAXIS 2D was chosen. The heterogeneous nature of the Venetian soils would require a very thorough $3 \mathrm{D}$ modelling, taking into account the spatial variability of soil characteristics. However, it was decided to keep the numerical model as simple as possible to better understand the applicability of numerical analysis to the Treporti test embankment case.

Laboratory and in situ measurements clearly showed the time-dependent behaviour of silty soils at the test site and in the whole lagoon area. Furthermore, it has been proven that during the formation process of natural soils an anisotropic fabric is created. Therefore, a further aim of this study is to investigate the influence of stress-induced anisotropy on the predictions of vertical and most importantly, horizontal 
displacements. To this end, the isotropic soft soil creep model (SSC) proposed by Vermeer and Neher [4] was used to model the creep behaviour of the most compressible layers. The second constitutive model applied to the creep analysis was the anisotropic creep model (ACM) recently developed at the University of Stuttgart [5]. The numerical results obtained with the two different constitutive models were then compared to the in situ measurements in order to assess the relevance of taking into account fabric anisotropy in the numerical analysis.

In the next section of the paper, the main characteristics of Venetian soils are reported, followed by the description of the Treporti test site embankment. In the second part, the numerical modelling of soil behaviour underneath the Treporti trial embankment is presented. Finally, some conclusions are drawn.

\section{Main Features of Venetian Soils}

The main feature of Venetian soils is the presence of a predominantly silty fraction, being a consequence of mechanical degradation of the original sand particles. The silt is always combined with clay and (or) sand, forming a chaotic interbedding of different sediments, whose basic mineralogical characteristics are, however, variable from site to site, in a relatively narrow range due to a unique geological origin and common depositional environment. Figure 1 shows the soil composition at the Treporti test site together with some relevant basic properties. The soil types have been reduced to the following three classes: medium-tofine sand (SP-SM), silt (ML), and silty clay (CL), according to the unified soil classification System. Sands appear to be relatively uniform, but moving towards finer materials, the grain-size curves display a larger range of particle diameters. Silts present intermediate characteristics between fine and coarse grained soils, and they can be classified as poorly structured materials. Due to sample disturbance, the shape of compression curves did not allow a clear determination of OCR from laboratory tests; therefore, OCR was estimated through in situ measurements [2].

In Figure 1, main features of the underlying soil layers are described as follows.

(i) From the soil grading reconstruction, the various types of soil occur up to $60 \mathrm{~m}$, approximately, in the proportion: SM-SP 22\%, ML 32\%, CL 37\%, and CHPt 9\%.

(ii) Upper and deeper sands are relatively uniform; finer materials are more graded, and the coarser the materials, the lower the coefficient $U$.

(iii) The unit weight $\gamma_{\text {sat }}$ and void ratio $e_{0}$ show large oscillations, the latter lying approximately in the range between 0.8 and 1.1, with higher values due to laminations of organic material.

The second column shows the diameter $D_{50}$, the uniformity coefficient $U=D_{60} / D_{10}$ together with the grain-size index $I_{\mathrm{GS}}=\left(D_{50} / D_{0}\right) / U\left(D_{0}=1 \mathrm{~mm}\right)$ proposed by Cola and Simonini [1] and relating some relevant soil parameters to

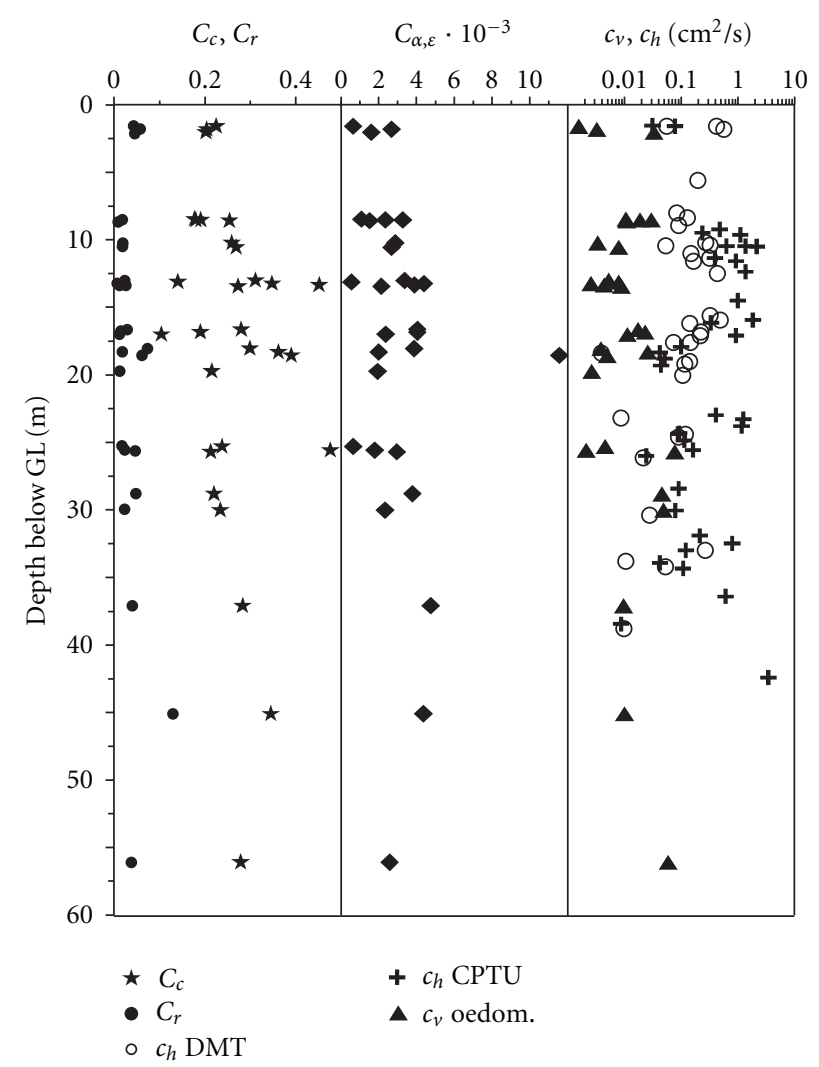

Figure 2: Profiles of compression indexes and consolidation coefficients at Treporti test site.

their grading properties. This material index is used in this paper to evaluate the model parameters values used in the analysis through correlations proposed by Cola and Simonini [1].

The last column sketches the profile of OCR, estimated from oedometric test results on CL samples as well as from the interpretation of in situ stress-strain behaviour [2]. Note that according with in situ response, the soil appears to be slightly overconsolidated, with OCR decreasing towards unity with depth.

Figure 2 shows the compression and recompression coefficients $C_{c}$ and $C_{r}$, the coefficient of secondary compression $C_{\alpha \varepsilon}=\Delta \varepsilon / \Delta \log (t)$ as well as the consolidation coefficients of $c_{v}$ and $c_{h}$ estimated from laboratory and from in situ tests. The relevant variation with depth of the consolidation coefficient, characterized by higher $c_{h}$ with respect to $c_{v}$, proves that Venice lagoon silts are relatively free draining soils, especially in the horizontal direction.

\section{The Trial Embankment: Construction and Removal Phases and Displacements Measures}

The reinforced embankment construction started in September, 12th 2002 and ended in March, 10th 2003 and was carried out in 14 stages. The bank is formed by 13 polypropylene geogrid-reinforced sand layers with $0.5 \mathrm{~m}$ thickness, reaching a final height of $6.7 \mathrm{~m}$. The fill was dynamically 
Section N-S

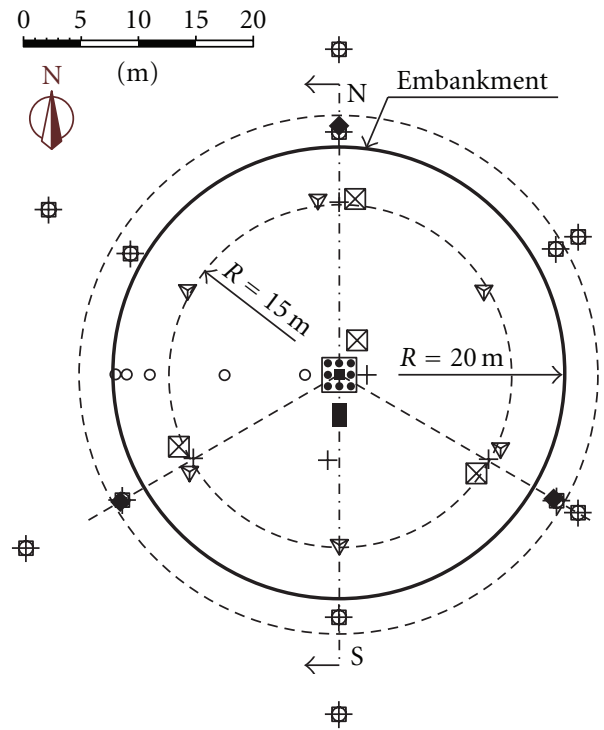

- Settlement plate and GPS receiver

- Rod extensometer $\otimes$ Sliding micrometer

+ Vibrating-wire piezometer

(a)
- Load cell

- Casagrande piezometer

- Inclinometer

中 Bench mark

$\checkmark$ Settlement plate

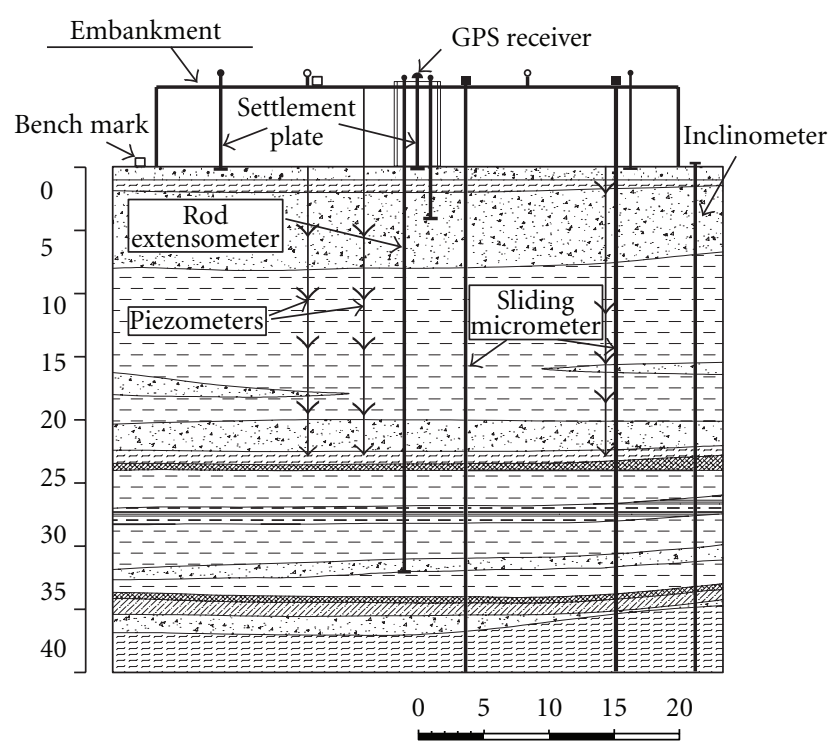

(m)

FIGURE 3: Treporti embankment horizontal and vertical section: instrumentation positioning.

TABLE 1: Embankment construction and removal phases.

\begin{tabular}{|c|c|c|c|}
\hline Phase & Date & Fill height $(\mathrm{m})$ & Action \\
\hline 0 & 12 September 2002 & 0.00 & reference measurement \\
\hline 1 & 12-17 September 2002 & 0.5 & $+0.5 \mathrm{~m}$ sand \\
\hline 2 & 23-26 September 2002 & 1.00 & $+0.5 \mathrm{~m}$ sand \\
\hline 3 & 1-3 October 2002 & 1.50 & $+0.5 \mathrm{~m}$ sand \\
\hline 4 & 9-14 October 2002 & 2.00 & +0.5 sand \\
\hline 5 & 7-8 November 2002 & 2.50 & +0.5 sand \\
\hline 6 & 13-18 November 2002 & 3.00 & +0.5 sand \\
\hline 7 & 27-29 November 2002 & 3.50 & +0.5 sand \\
\hline 8 & 16-19 December 2002 & 4.00 & +0.5 sand \\
\hline 9 & 30 December 2002-03 January 2003 & 4.50 & +0.5 sand \\
\hline 10 & 14-16 January 2003 & 5.00 & +0.5 sand \\
\hline 11 & 22-25 January 2003 & 5.50 & +0.5 sand \\
\hline 12 & 4-7 February 2003 & 6.00 & +0.5 sand \\
\hline 13 & 24-27 February 2003 & 6.50 & +0.5 sand \\
\hline 14 & 06-10 March 2003 & 6.70 & +0.2 gravel \\
\hline 15 & 15-29 June 2007 & $5.40 \mathrm{ca}^{*}$ & -0.2 gravel, -0.5 sand \\
\hline 16 & 8-14 July 2007 & 4.60 ca. $^{*}$ & -0.8 sand \\
\hline 17 & 22 October-06 November 2007 & 3.60 ca. $^{*}$ & -1.0 sand \\
\hline 18 & 9-20 November 2007 & 2.65 ca. $^{*}$ & -0.95 sand \\
\hline 19 & 22 February-4 March 2008 & 1.70 ca. $*^{*}$ & -0.95 sand \\
\hline 20 & 17-21 March 2008 & 0.75 ca. $*^{*}$ & -0.95 sand \\
\hline 21 & 26-31 March 2008 & $0.00^{*}$ & -0.75 sand \\
\hline
\end{tabular}

\footnotetext{
${ }^{*}$ The reference height is not exactly at the centreline, but at a distance where, after the creep settlement, the embankment height is $6.30 \mathrm{~m}$.
} 


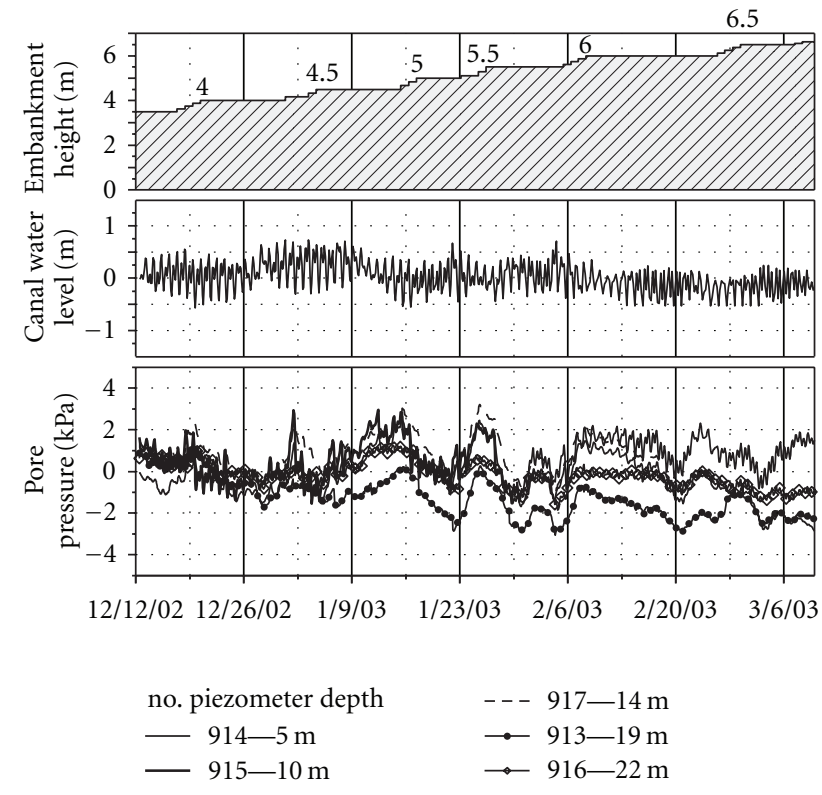

FIGURE 4: Piezometers readings during embankment construction.

compacted to give a dry unit weight $=15.6 \mathrm{kN} / \mathrm{m}^{3}$. Threemeter-long prefabricated vertical drains were first installed to speed up the drainage of a shallow clay layer and to prevent possible lateral soil spreading during construction. Embankment removal has been carried out from June, 15th 2007 until March, 31st in three phases. Table 1 describes construction and removal of the embankment in more detail.

The instrumentation installed at Treporti test site was designed to monitor the following quantities:

(i) surface vertical displacements using 7 settlement plates, 12 bench marks, and one GPS antenna, located in the centre of the embankment area and fixed to the central settlement plate,

(ii) vertical deep displacements by means of 8 borehole rod extensometers,

(iii) local vertical displacements, along with four verticals, using 4 special multiple extensometers,

(iv) horizontal displacements by means of 3 inclinometers;

(v) pore water pressure in fine-grained soils by means of 5 Casagrande as well as 10 vibrating wire piezometers,

(vi) total vertical stress beneath the loading embankment by means of 5 load cells.

In particular, to measure the vertical displacements throughout the foundation ground very precisely, multiple micrometers, capable of measuring vertical displacements at $1 \mathrm{~m}$ intervals with an adequate degree of accuracy of $0.03 \mathrm{~mm} / \mathrm{m}$ were selected. Figure 3 shows a schematic soil profile together with the position of monitoring devices.

The presence of prefabricated drains in the upper silty clay layer and the relatively high soil drainage of all the deeper layers suggested that primary consolidation should have been quite rapid and contemporary with the embankment construction. In other words, little deformation due to consolidation should have been observed, considering that the rate of load increase, required by the earth-reinforcement construction technique, was low compared to the drainage conditions of the deposit. This hypothesis seemed to be confirmed by the electric piezometer readings (Figure 4), which gave no detectable pore pressure increase in any layer: the variation of pore pressure in the piezometers appeared to be mostly controlled by the daily oscillations of the sea tide in the channel facing the embankment area rather than by the increasing load. Casagrande piezometers measured a maximum water excursion of around $0.4 \mathrm{~m}$ during the whole construction interval.

Figure 5 shows the evolution with time of the load and of the ground settlement measured under the centre of the embankment (GPS and topographic survey), near the centre (multiple extensometer SD3) and at a distance of $15 \mathrm{~m}$ from the centreline (multiple extensometer SD1). The total settlement on embankment completion (around 180 days) under the centreline was $380 \mathrm{~mm}$. Until the last measurement before the unloading phases (April 2007), an additional secondary settlement at constant load of $140 \mathrm{~mm}$ was measured, thus giving a total settlement of $520 \mathrm{~mm}$. The swelling recovery was very little compared to the total displacement before unloading. In the centreline of the embankment, a heave of approximately $30 \mathrm{~mm}$ was measured during unloading.

The same behaviour is shown by the lateral multiple micrometer (SD1): the overall displacement is as expected less than under the centreline. Recovery swelling is also here rather small, that is, approximately $25 \mathrm{~mm}$.

A complete overview of the vertical profile along the embankment diameter is reported in Figure 6. It is clearly noticeable that the settlement occurred in a delimited area under the embankment, probably due to the poor shear resistance capability of Venice lagoon soils, so that the settlement did not spread around. In fact, horizontal displacements are relatively small compared to vertical displacements. Figure 6 also depicts how small the vertical upheaval is compared to vertical settlement upon primary loading.

In Figures 7(a) and 7(b), local and total displacement along with depth are plotted for SD3 near the centreline and SD1 at a distance of $15 \mathrm{~m}$, respectively. The strain profiles can give an interpretation of the soil profile: the higher the local settlement, the higher the fraction of silt and clay in the soil. The layering is basically identical for both surveys. However, overall settlement is different. As regards the swelling displacement, the grey pattern in the total displacement profile shows that its amount is relatively small, indicating high soil stiffness in unloading.

\section{Numerical Modelling}

4.1. Soil Layering. From $I_{\mathrm{GS}}$ index value for the entire vertical profile (Figure 1, second column), by means of empirical correlations [1], the main soil features were assessed. Therefore, six homogeneous soil formations were identified. 

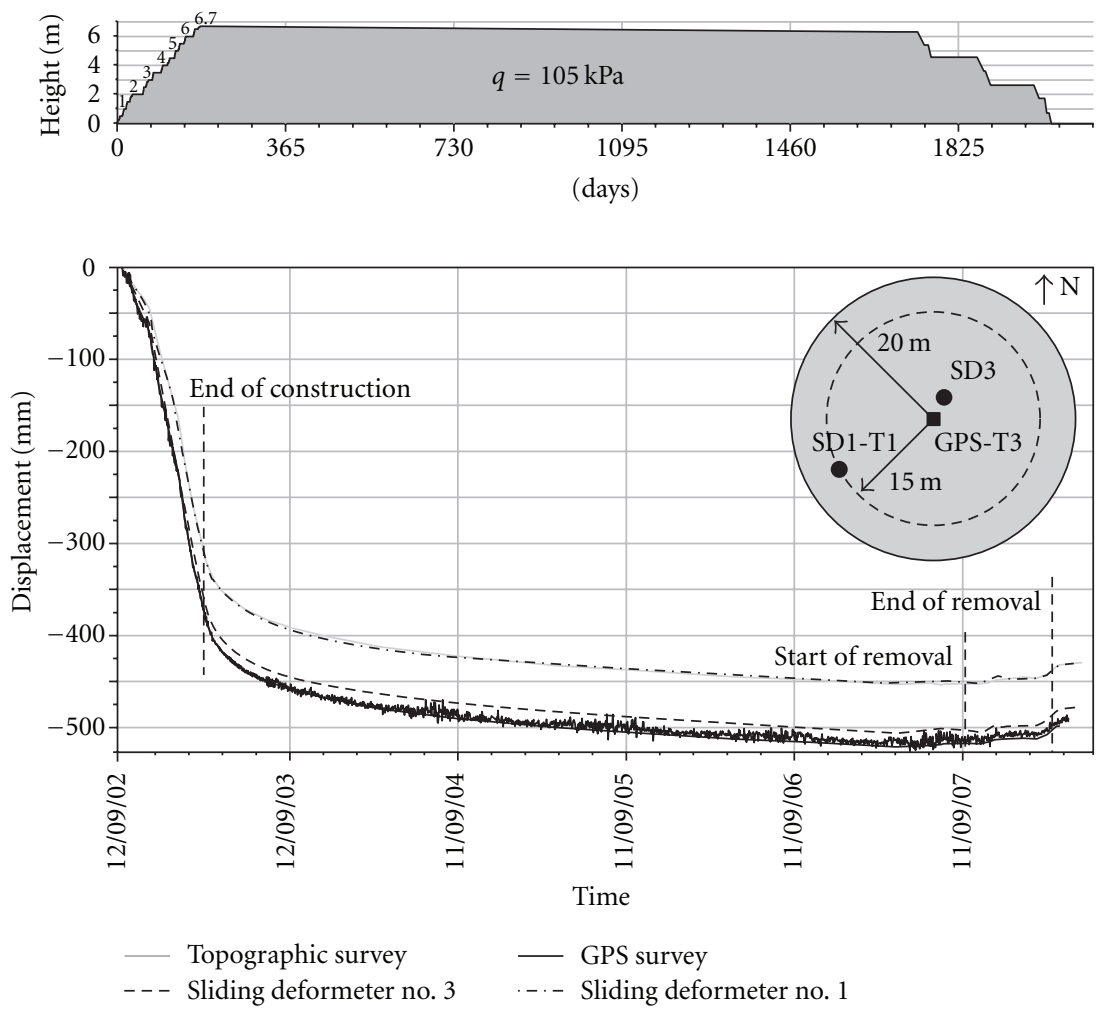

FIGURE 5: Vertical displacement near the centreline and at a distance of $15 \mathrm{~m}$.

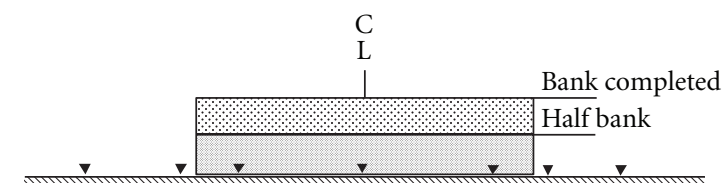

Radius (m)

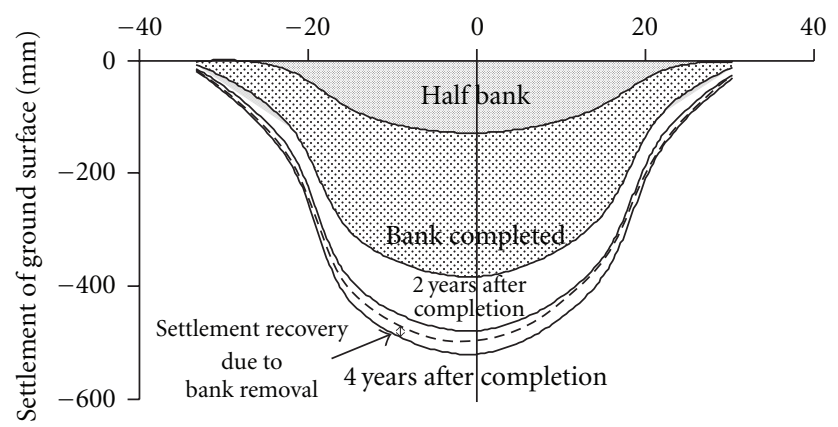

$\boldsymbol{\nabla}$ Position of settlement measurements

FIGURE 6: Vertical displacement profile along with the embankment diameter.

The soil layers distribution assumed for numerical analysis is shown in Figure 8. The first soil type (formation A) is an overconsolidated clay, which can be found in the topmost soil layer. Silty sand (B) is mainly found in the second layer.
The third soil formation (C), a lightly overconsolidated silt with low content in clay and sand, was assigned to the third and fifth layers. The fourth soil formation (D) is a sand, and it is found in the fourth soil layer. The deepest layers can be described by the sandy formations (E) and (F).

As for the constitutive laws applied, the elastoplastic inviscid hardening soil model [6] was chosen for soil layers in which the sand was the main component (B, D, E, and F) and for formation $\mathrm{A}$ in which creep behaviour is negligible because of high OCR.

In order to model long-term behaviour of the soft layers with a dominant silty or clayey fraction (formation $\mathrm{C}$ ), the isotropic soft soil creep model [4] was used. Furthermore, to investigate the effect of fabric anisotropy, the newly developed anisotropic creep model [5] was used, too.

In the latter model, anisotropy is taken into account by introducing a rotation in the isotropic ellipses of modified cam clay used in soft soil creep model. Furthermore, a rotational hardening law has been introduced to describe the rate of rotation with viscous shear and volumetric strain rates. An exhaustive description of the two constitutive models goes beyond the scope of this paper. The interested reader is referred to Vermeer and Neher [4] and Leoni et al. [5] for the full formulation of the isotropic and anisotropic creep models, respectively.

4.2. Parameter Identification. The use of the isotropic soft soil creep model requires the identification of the critical state 

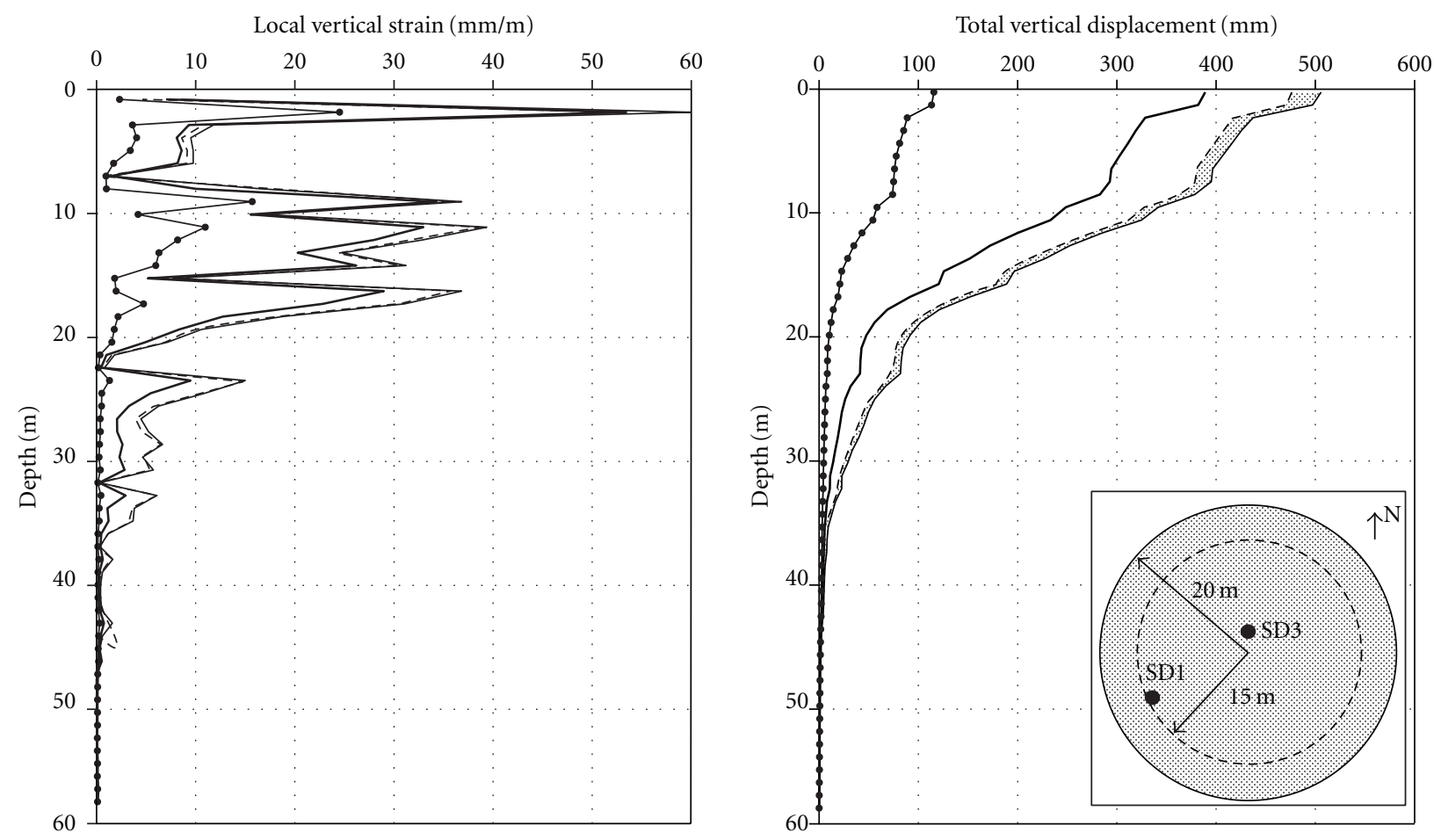

(a)

Local vertical strain $(\mathrm{mm} / \mathrm{m})$

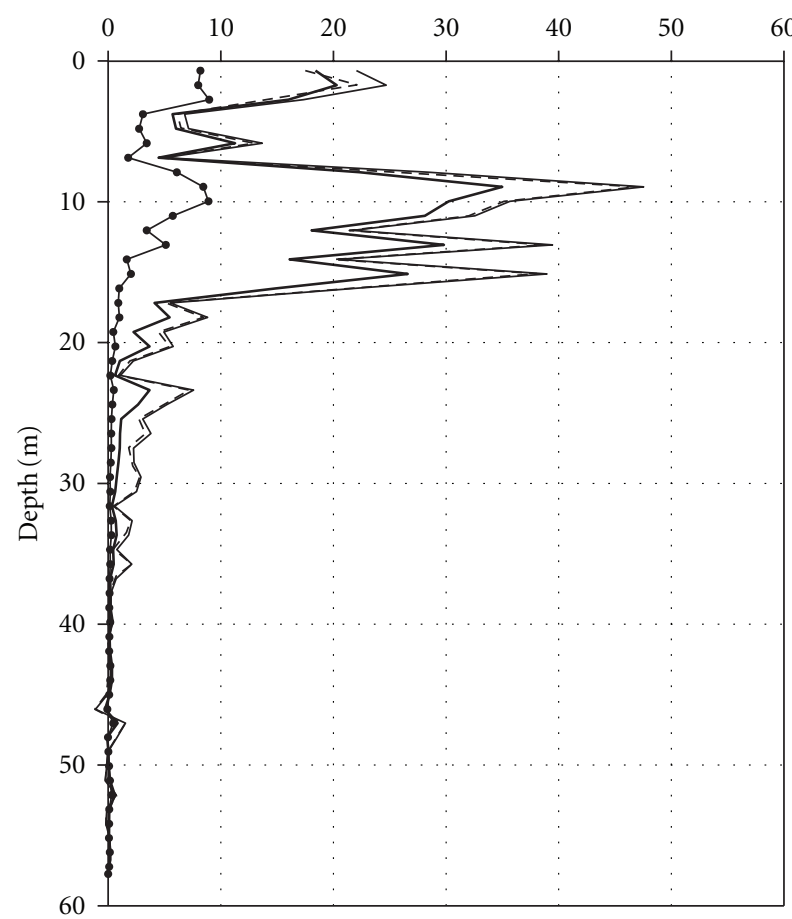

Total vertical displacement $(\mathrm{mm})$

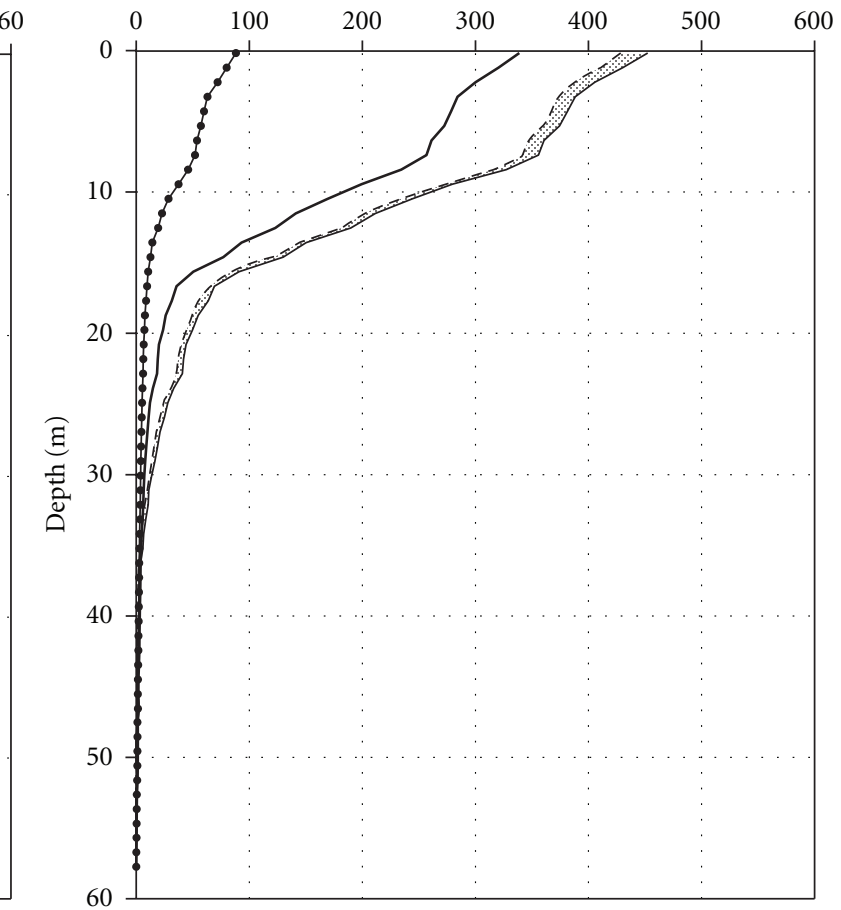

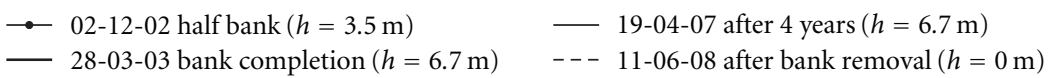

(b)

FIGURE 7: Local and total displacements profile along with depth (a) near the centreline (b) at $r=15 \mathrm{~m}$ from the centreline. 
TABLE 2: Soft soil creep/anisotropic creep model parameters.

\begin{tabular}{|c|c|c|c|c|c|c|c|c|c|c|}
\hline layer & depth $[\mathrm{m}]$ & $\gamma_{\text {sat }}\left[\mathrm{kN} / \mathrm{m}^{3}\right]$ & $\gamma\left[\mathrm{kN} / \mathrm{m}^{3}\right]$ & $\lambda^{*}$ & $\kappa^{*}$ & $\mu^{*}$ & $c\left[\mathrm{kN} / \mathrm{m}^{2}\right]$ & $\varphi\left[^{\circ}\right]$ & $\psi\left[{ }^{\circ}\right]$ & $v$ \\
\hline $\mathrm{C}$ & $\begin{array}{c}8-16 \\
19-45\end{array}$ & 18.8 & 18 & 0.024 & 0.0048 & 0.0012 & 1 & 33 & 0 & 0.15 \\
\hline
\end{tabular}

TABLE 3: Hardening soil model parameters.

\begin{tabular}{|c|c|c|c|c|c|c|c|c|c|c|}
\hline layer & depth $[\mathrm{m}]$ & $\gamma_{\text {sat }}\left[\mathrm{kN} / \mathrm{m}^{3}\right]$ & $\gamma\left[\mathrm{kN} / \mathrm{m}^{3}\right]$ & $E_{50}\left[\mathrm{kN} / \mathrm{m}^{2}\right]$ & $E_{\text {oed }}\left[\mathrm{kN} / \mathrm{m}^{2}\right]$ & $E_{\mathrm{ur}}\left[\mathrm{kN} / \mathrm{m}^{2}\right]$ & $c\left[\mathrm{kN} / \mathrm{m}^{2}\right]$ & $\varphi\left[{ }^{\circ}\right]$ & $\psi\left[{ }^{\circ}\right]$ & $M$ \\
\hline A & $0-2$ & 18.65 & 18.4 & $3 \cdot 10^{4}$ & $3 \cdot 10^{4}$ & $1.2 \cdot 10^{5}$ & 1 & 32 & 0 & 0.5 \\
\hline B & $2-8$ & 18.5 & - & $3 \cdot 10^{4}$ & $3 \cdot 10^{4}$ & $1.2 \cdot 10^{5}$ & 1 & 36 & 0 & 0.5 \\
\hline $\mathrm{D}$ & $16-19$ & 18.4 & - & $3 \cdot 10^{4}$ & $3 \cdot 10^{4}$ & $1.2 \cdot 10^{5}$ & 1 & 34 & 0 & 0.5 \\
\hline E & $45-55$ & 18.2 & - & $3 \cdot 10^{4}$ & $3 \cdot 10^{4}$ & $1.2 \cdot 10^{5}$ & 1 & 35 & 0 & 0.5 \\
\hline $\mathrm{F}$ & $55-60$ & 18 & - & $3 \cdot 10^{4}$ & $3 \cdot 10^{4}$ & $1.2 \cdot 10^{5}$ & 1 & 33 & 0 & 0.5 \\
\hline
\end{tabular}

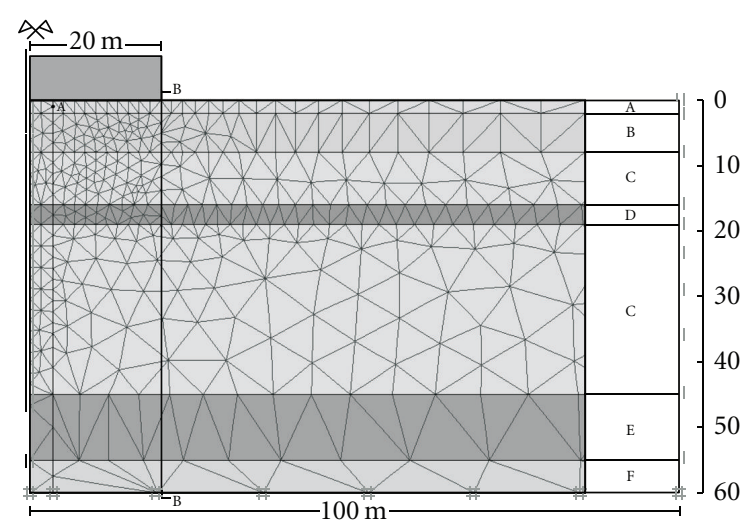

Figure 8: Finite element mesh. Right column: soil type (A to F) assigned to each layer.

friction angle (assuming that cohesion $c$ to be zero for typical soft soils) and of the modified compression, swelling and creep index $\left(\lambda^{*}, \kappa^{*}\right.$, and $\mu^{*}$, resp. $)$.

In the past, an empirical formula was proposed to relate the critical state friction angle to the previously defined $I_{\mathrm{GS}}$ index [1]

$$
\varphi_{c}^{\prime}=(38.0 \pm 2.0)+1.55 \cdot \log I_{\mathrm{GS}}
$$

The modified creep index $\mu^{*}=C_{\alpha \varepsilon} / \ln 10$ was determined on the basis of vertical strain versus $\ln (t)$ plots of $24 \mathrm{~h}$ standard oedometer tests. No doubt, due to soil disturbance during sampling, the oedometric stiffness $\lambda^{*}$ would be an unreliable indicator of the true value; therefore, its value has been also estimated by using the empirical correlation $\lambda^{*} \approx 20 \cdot \mu^{*}[7]$. In order to further verify the reliability of such assumption, the obtained values were compared with those obtained with the correlation existing between the material index $I_{\mathrm{GS}}$ and the compression index $\lambda_{c}[1]$

$$
\lambda_{c}=(0.152 \pm 0.04)-0.037 \cdot \log I_{\mathrm{GS}}
$$

The modified compression index $\lambda^{*}$ was then evaluated by its definition $\lambda^{*}=\lambda_{c} /\left(1+e_{0}\right) / \ln 10$. The values computed with the two independent methods, as described above, were in good agreement and, therefore, adopted for numerical analysis. The modified swelling index $\kappa^{*}$ was taken as $\lambda^{*} / 5$ [7]. All the indexes resulted to lie within the range shown in Figure 2.

In Figure 9(a), one of the typical calibration test results is presented. The soil specimens used for the tests come from different depths, but all belong to the most silty layers (formation C).

The use of the anisotropic model requires, besides the compression indexes already introduced, the definition of the initial rotation of the ellipse. The components of the initial fabric tensor can be expressed in terms of the critical state friction angle assuming that the undisturbed soil is in an initial $K_{0}$-consolidated state [8]. In the definition of the rotational hardening law describing the evolution of the fabric tensor with creep strain rates, two extra parameters are involved. However, on the basis of simple considerations, they can be expressed in terms of critical state friction angle and modified compression index $\lambda^{*}[5,8]$. Therefore, the values of the additional soil parameters dealing with anisotropy are completely determined as function of those used in the isotropic soft soil creep model.

In addition to the calibration tests, two long-term oedometer tests were performed (Figure 9(b)), in which the load was doubled every seven days. These latter tests showed the typical behaviour that can be observed in natural clays, as observed, for example, by Kim and Leroueil [9]: instead of the characteristic S-shape curve, typically seen in 24 hour tests, the vertical strain versus $\log (t)$ plot shows a straight line in the beginning. Later the steepness of the plot increases towards $C_{\alpha \varepsilon}$. This feature is well captured by isotropic and anisotropic creep models, as presented by Berengo [10]. The experimental tests were reproduced with PLAXIS code, thus showing a good agreement with measured values.

The parameters of the hardening soil model were set to typical values for sandy materials. No particular calibration effort was devoted to the calibration of these material parameters, considering that the aim of this study is to model viscous behaviour of soft silty layers.

In order to properly set the initial conditions, the overconsolidation ratio is necessary. OCR values are selected following the profile shown in last column of Figure 1: higher 


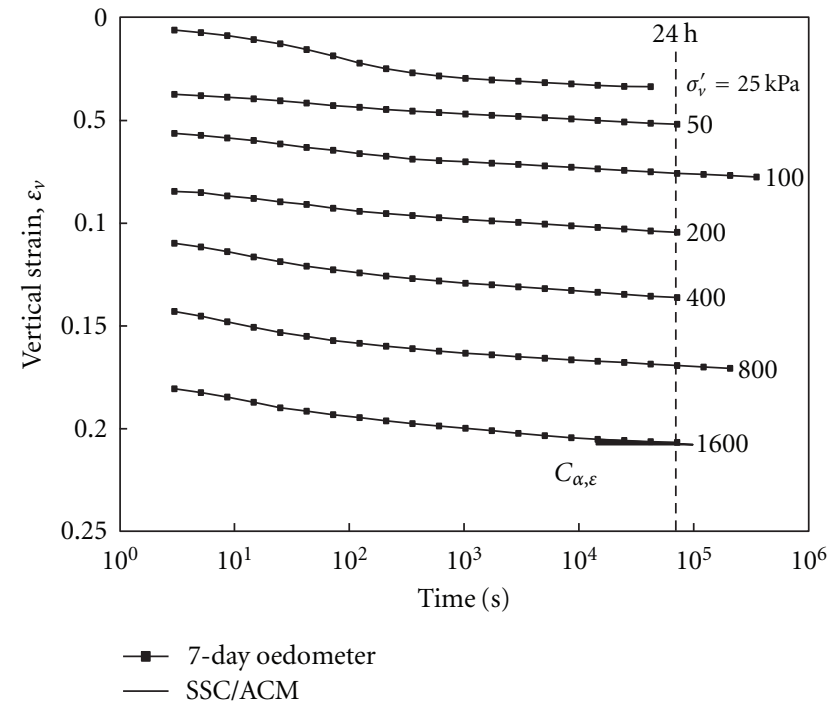

(a)

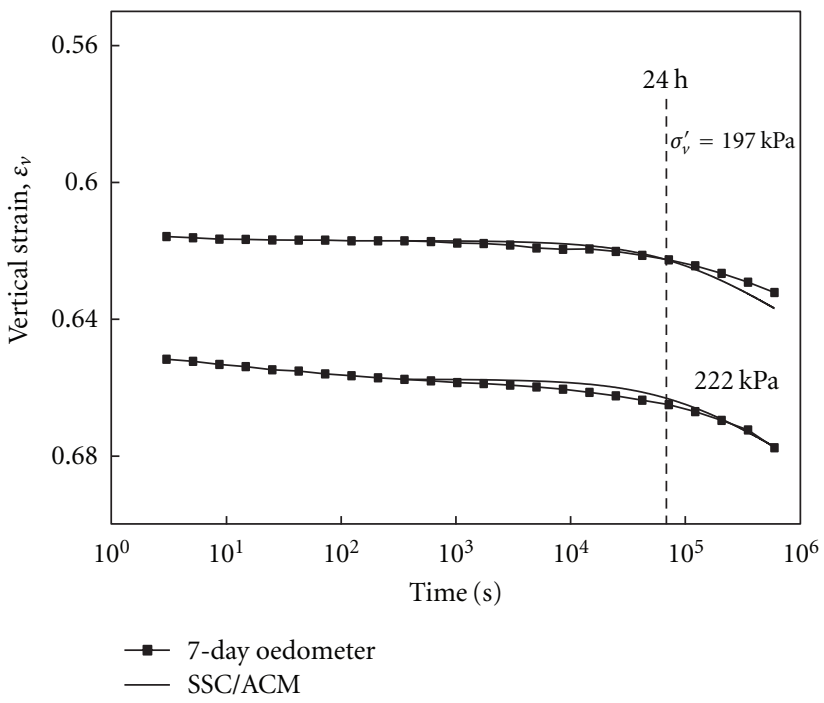

(b)

Figure 9: (a) Standard 24 h oedometer test; (b) Long-term 7-day oedometer test.

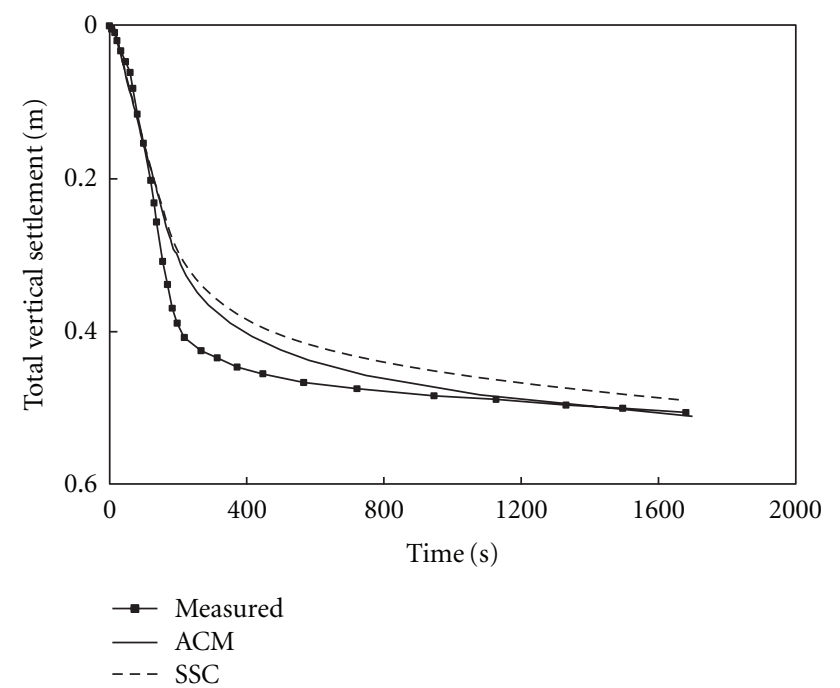

FIgURE 10: Vertical settlement at the embankment centreline.

layers are strongly overconsolidated, whilst deeper ones are slightly overconsolidated.

The complete set of material parameters used for FE analyses is summarized in Tables 2 and 3 .

The embankment was modelled with a simple linear elastic constitutive law. Young's modulus of the latter was calibrated through back analysis of the stress distribution measured by pressure cells, in order to reproduce the measured one through numerical analysis, thus resulting in $\mathrm{E}=10^{6} \mathrm{kPa}$.

4.3. Numerical Modelling of Treporti Test Embankment. Horizontal displacements were prevented along the symmetry axis at the left-hand side of the mesh and at the righthand side, whilst horizontal and vertical displacements were prevented at the bottom of the mesh.

As for the hydraulic boundary conditions, the water table was assumed to be $0.5 \mathrm{~m}$ below ground surface and horizontal water flow was prevented along the symmetry axis. The construction and removal phases of the test embankment were simulated by activating the soil layers according to the real construction sequence. Each soil layer was applied in an undrained phase followed by a consolidation phase. In each phase, the pore water pressure generated during the previous phase added to the excess pore pressure continuously generated by creep was so dissipated through consolidation.

4.4. Results of Numerical Modelling-Construction Phases and Creep. To compare the results obtained to in situ measurements, the vertical settlement under the centre of the embankment is plotted versus time in Figure 10. The total vertical settlement, measured with the sliding micrometer near the embankment centreline at the half of the first layer (Figure 8, point A) was compared to the total vertical settlement predicted by finite elements, both with isotropic and anisotropic creep models. The overall stiffness of the subsoil is slightly larger than the calculated one, but the final settlement is well captured by the two creep models. The anisotropic model is in better agreement with the measurements.

The good performance of the anisotropic model is confirmed when horizontal displacements close to the embankment toe (Figure 8, vertical B) are considered in different times after the end of construction. The horizontal displacement measured at the end of construction in Figure 11(a) is underestimated by the isotropic model, whilst 


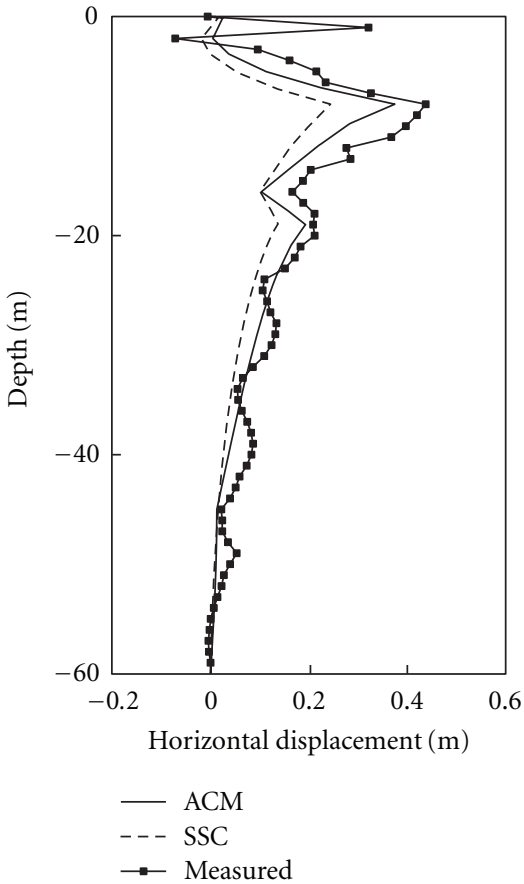

(a)

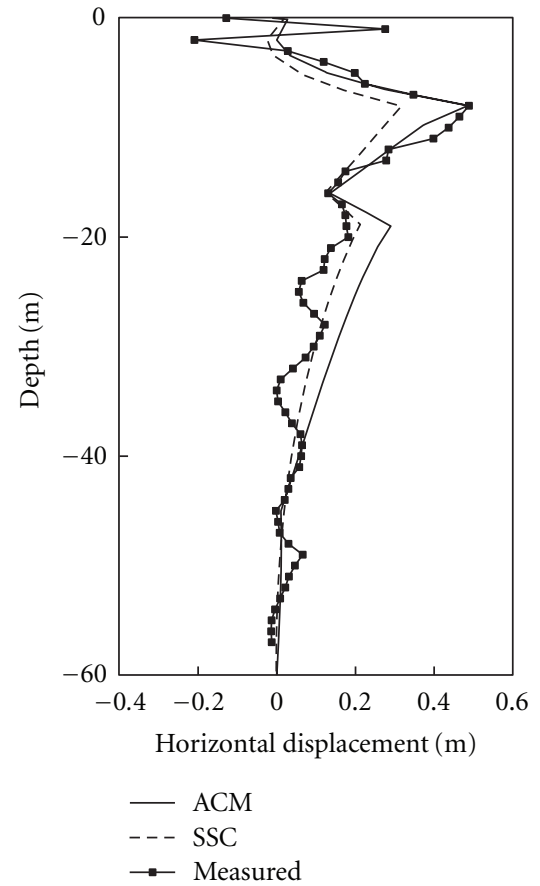

(b)

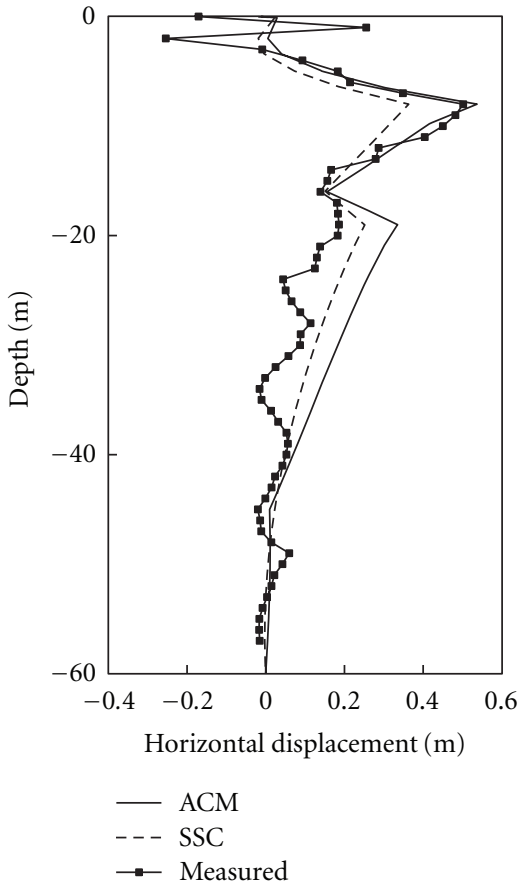

(c)

FIGURE 11: Horizontal displacements (a) at the end of construction, (b) after one year, and (c) after four years.

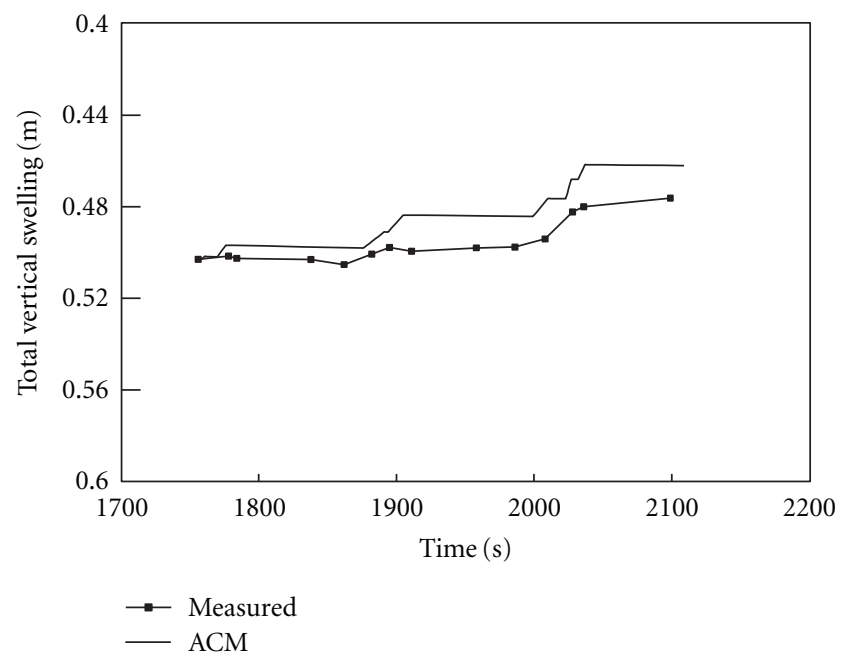

FIGURE 12: Vertical swelling under the embankment centreline in unloading phases.

the anisotropic model is in better agreement with measured data for the whole depth. In Figure 11(b) the numerical prediction of the anisotropic formulation is good in the topmost soft layer and deteriorates slightly with increasing depth. The soft soil creep model still underestimates the horizontal deformation in topmost layers, whilst its prediction improves with depth. Figure 11(c) shows the settlement after four years. The predicted values are still very good for the anisotropic creep model close to the ground surface, and then, horizontal displacements are overestimated going deep towards the bottom side of the mesh. The isotropic model confirms its general tendency to underestimate the displacement, which brings to a better prediction in the deepest part of the model. It is worth noting that this difference in the two creep models is given only by the rotation of the constitutive surfaces, since exactly the same constitutive parameters are used in both models.

4.5. Results of Numerical Modelling-Removal Phases and Swelling: Future Research. Since the anisotropic model has shown better results in modelling loading and creep phases compared to the isotropic one, it has been used to simulate unloading, as well. Upon unloading, the model clearly overestimates the overall swelling behaviour, as shown in Figure 12. For each of the three removal phases, the predicted recovery displacement is higher than the measured one whereas for the constant load phases the model does not show any creep settlement because of the high OCR due to unloading. On the other hand, field measurements still show creep settlement after the first removal phases, a constant displacement after the second removal phase, and even further swelling displacement in time after the third removal.

The first feature (limited swelling upon unloading) can be incorporated in the model taking into account small strain stiffness behaviour of natural soils throughout a strain dependent stiffness modulus. The modification has already been implemented in the anisotropic model with encouraging results as described in Berengo et al. [11]. 


\section{Conclusions}

The overall good numerical results show the suitability of numerical analysis for capturing the mechanical behaviour of Venetian subsoils. Nevertheless, it is necessary to make use of constitutive laws incorporating creep for modelling the stress-strain-time behaviour of silty fraction. The real behaviour of naturally deposited soils can be more elegantly modelled by incorporating anisotropy in the viscous constitutive model. Furthermore, the overall observation of numerical results confirms the improvement obtained in terms of predicted horizontal displacements. As regards the little swelling vertical displacement shown in unloading phases, it is necessary to introduce a strain-dependent stiffness modulus in order to better catch the experimental stiff behaviour. This latter improvement has already been studied and implemented in the model with very good results.

\section{References}

[1] S. Cola and P. Simonini, "Mechanical behavior of silty soils of the Venice lagoon as a function of their grading characteristics," Canadian Geotechnical Journal, vol. 39, no. 4, pp. 879-893, 2002.

[2] P. Simonini, G. Ricceri, and S. Cola, "Geotechnical characterization and properties of Venice lagoon heterogeneous silts," in Proceedings of the 2nd International Workshop on Characterization and Properties of Natural Soils, vol. 4, pp. 2289-2327, Balkema, Rotterdam, 2006.

[3] V. Berengo, Constitutive modelling of the time-dependent behaviour of Venice heterogeneous silts, Ph.D. thesis, University of Padova, 2010.

[4] P. A. Vermeer and H. P. Neher, "A soft soil model that accounts for creep," in Proceedings of the International Symposium "Beyond 2000 in Computational Geotechnics", pp. 249-261, 1999.

[5] M. Leoni, M. Karstunen, and P. A. Vermeer, "Anisotropic creep model for soft soils," Geotechnique, vol. 58, no. 3, pp. 215-226, 2008.

[6] T. Schanz, P. A. Vermeer, and P. G. Bonnier, "The hardening soil model: formulation and verification," in Proceedings of the International Symposium "Beyond 2000 in Computational Geotechnics", pp. 281-296, Amsterdam, The Netherlands, 1999.

[7] F. H. Kulhawy and P. W. Mayne, Manual of Estimating Soil Properties for Foundation Design, Cornell University, Ithaca, NY, USA, 1990.

[8] S. J. Wheeler, A. Näätänen, M. Karstunen, and M. Lojander, "An anisotropic elastoplastic model for soft clays," Canadian Geotechnical Journal, vol. 40, no. 2, pp. 403-418, 2003.

[9] Y. T. Kim and S. Leroueil, "Modeling the viscoplastic behaviour of clays during consolidation: application to Berthierville clay in both laboratory and field conditions," Canadian Geotechnical Journal, vol. 38, no. 3, pp. 484-497, 2001.

[10] V. Berengo, Modellazione costitutiva del comportamento viscose dei terreni di Venezia, Degree thesis, University of Padova, 2006.

[11] V. Berengo, T. Benz, P. Simonini, and M. Leoni, "Formulation and application of a small strain creep model," submitted. 

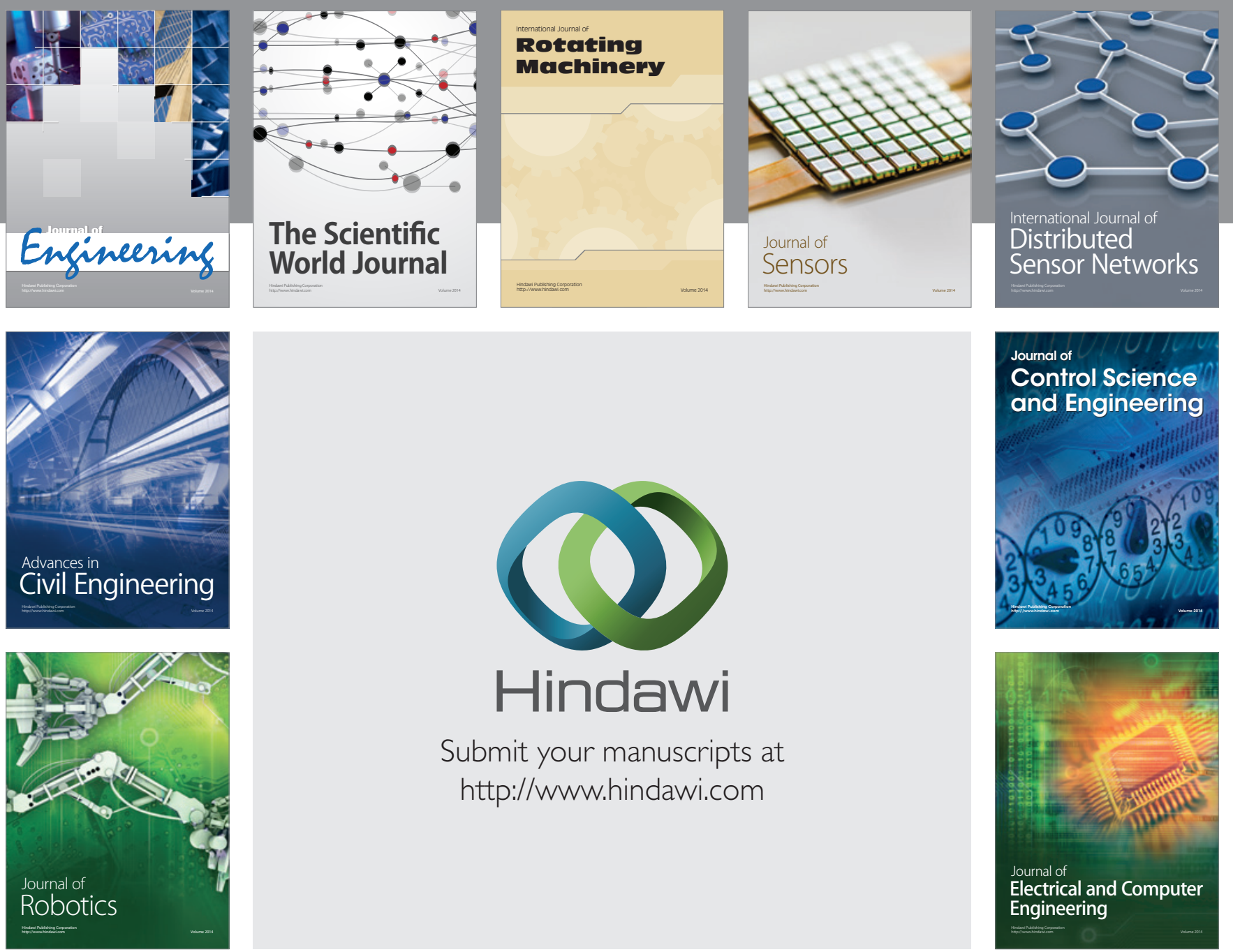

Submit your manuscripts at

http://www.hindawi.com
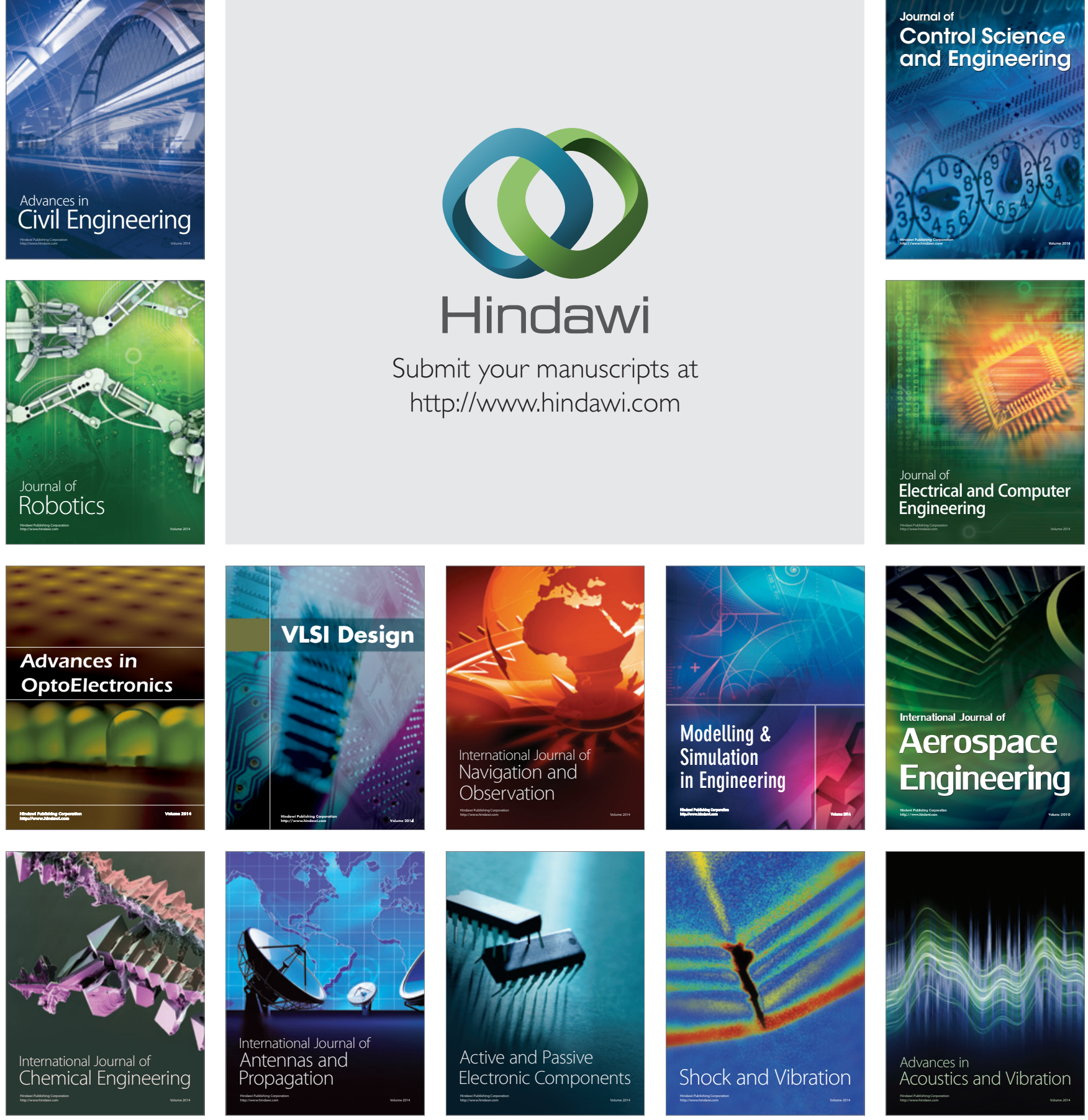